\title{
GLOBAL PRODUCTION CONCENTRATION OF MEDIUM DENSITY FIBERBOARD (MDF) $\left(1995\right.$ - 2016) ${ }^{1}$
}

Thaisa de Sousa Selvatti ${ }^{2}$, Luis Antônio Coimbra Borges ${ }^{3}$, Helena Cristina Carvalho Soares ${ }^{4}$, Álvaro Nogueira de Souza ${ }^{5}$ and Luiz Moreira Coelho Junior ${ }^{6 *}$

\footnotetext{
${ }^{1}$ Received on 12.03.2018 accepted for publication on 018.09.2018.

${ }^{2}$ Universidade Federal de Lavras, Programa de Pós-Graduação em Engenharia Florestal, Lavras, MG-Brasil. E-mail: $<$ thaisaselvatti@gmail.com>.

${ }^{3}$ Universidade Federal de Lavras, Departamento de Ciências Florestais, Lavras, MG-Brasil. E-mail: <luis.borges@dcf.ufla.br>.

${ }^{4}$ Universidade de Brasília, Faculdade de Tecnologia, Programa de Pós-Graduação em Ciências Florestais, Brasília,DF-Brasil. E-mail: <helena.soares@cear.ufpp.br>.

${ }^{5}$ Universidade de Brasília, Faculdade de Tecnologia, Departamento de Engenharia Florestal, Brasília,DF-Brasil. E-mail:

<ansouza@unb.br>.

${ }^{6}$ Universidade Federal da Paraíba, Departamento de Engenharia de Energias Renováveis, João Pessoa,PB-Brasil. E-mail:

$<$ luiz@cear.ufpb.br>

*Corresponding author.
}

\begin{abstract}
This papaer analyzed the global MDF production and its concentration degree between 1995 and 2016. In order to measure and analyze this concentration, we used the Concentration Ratio [CR(k)], the Herfindahl-Hirschman Index (HHI), Theil Entropy Index (E), Hall and Tideman Index (HTI), the Comprehensive Concentration Index (CCI), and the Gini Index (G). Global MDF production grew $12.81 \%$ p.a. from 1995 to 2016 , reaching 99 million $\mathrm{m}^{3}$ at the end of the time series. China took over the hegemony in 2001 and arrived in 2016 with about $60 \%$ of the world's MDF supply. The CR(k) of the global MDF production inferred a high concentration, mainly in the CR(4) from 2009. The CR(8) remained with a moderately high average concentration. During this period more than $90 \%$ of the offer was retained in the CR(20). The HHI, E and HTI indices corroborate that there is high concentration in global MDF production, as well as the CCI in the studied period. The inequality indicated by $\mathrm{G}$ also presented increasing behavior and was classified as strong and very strong. The concentration indicators were efficient in evaluating the concentration degree of the world MDF supply.
\end{abstract}

Keywords: Forest economics; Market share; Concentration indicators.

\section{CONCENTRAÇÃO MUNDIAL DA PRODUÇÃO DE MEDIUM DENSITY FIBERBOARD (MDF) (1995 - 2016)}

\begin{abstract}
RESUMO - Este trabalho analisou a produção mundial de MDF e o seu grau de concentração, entre os anos de 1995 e 2016. Para mensurar e analisar esta concentração foram usados a Razão de Concentração [CR(k)], o Índice de Herfindahl-Hirschman (HHI), o Índice de Entropia de Theil (E), o Índice de Hall e Tideman (HTI), o Índice de Concentração Compreensível (CCI) e o Índice de Gini (G). A produção de mundial de MDF cresceu 12,81\% a.a., no periodo de 1995 a 2016, chegando a 99 milhões de m3 no final da série temporal. A China assumiu a hegemonia em 2001 e chegou em 2016 com cerca de $60 \%$ da oferta mundial de MDF. $O C R(k)$ da produção mundial de MDF inferiu uma alta concentração, principalmente, no CR(4) a partir de 2009. O CR(8) manteve-se com uma média de concentração moderadamente alto. Nesse periodo mais de $90 \%$ da oferta ficaram retidas no CR(20). Os índices HHI, E e HTI corroboram de que há alta concentração na produção mundial de MDF, assim como o CCI no periodo estudado. A desigualdade indicada pelo $G$ também apresentou comportamento crescente e foi classificada em forte e muito forte. Os indicadores de concentração se mostraram eficientes em avaliar o grau de concentração da oferta mundial de MDF.
\end{abstract}

Palavras-Chave: Economia florestal; Market share; Indicadores de concentração. 


\section{INTRODUCTION}

Wood and its by-products have several purposes for humanity. Among forest products, wood panels use a structure in sheets or disaggregated. To bond and to form the panel the wood undergoes pressure, temperature and resin action. Its main advantage comes from substituting solid wood in manufacturing furniture, doors, floors, baseboards, etc. There are two groups of panels, namely reconstituted and compensated panels, with the main difference being the processing form of the wood. While the former uses fibers or particles, the latter uses sheets (Biazus et al., 2013; IBÁ, 2014).

Medium Density Fiberboard (MDF) was designed for noble purposes. MDF has excellent physical properties that guarantee workability and machinability, mainly in the furniture industry and civil construction. It originated in 1970, and started production and export records by the United Nations Food and Agriculture Organization (FAO) only in 1995. In this year global MDF production was 7.88 million $\mathrm{m}^{3}$ by a total of 28 countries. The main producers were the United States (USA) (24.85\%), Italy (8.88\%), South Korea (7.27\%), Germany (7.14\%) and China (6.85\%) (Campos and Lahr, 2004; IBÁ, 2014, 2017; FAO, 2017).

The growing demand for wood-based products coupled with the scarcity of solid wood supply has enabled the technology of reconstituted wood panels to emerge. From 2000 to 2016 , global MDF production grew by around $10 \%$ p.a., although the wood panel supply grew at a lower rate. In 2001, China assumed the hegemony of world production, mainly to serve domestic consumption. In 2016, the international market produced 9.9 million $\mathrm{m}^{3}$ from 50 countries, with the main producers being China (59.63\%), Turkey (5.12\%), Brazil (4.05\%), Poland (3.59\%) and the United States (3.03\%) (FAO, 2014, FAO, 2017).

Economic development is associated with diversification strategies, especially in markets with little exploration, but with growth potential coupled with the need to achieve economies of scale and scope (Coelho Junior et al., 2013, 2016; Zheng and Kuroda, 2013). The need to evaluate the market structure of the international MDF market is useful to help decision making, either in guiding public policies or in establishing management strategies by firms. This evaluation as a form of quantifying the structural component plays a fundamental role within the structure-conduct- performance paradigm, with wide applications in studies on Industrial Economy (Zheng and Kuroda, 2013; Lopez et al., 2014)

An analysis of industrial concentration relates the market power exercised by firms and the competition. The concentration measures synthesize the productive structure into a single indicator that infers technological aspects, supply and demand related to the size and consolidation of the market power of a sector. Calculating the concentration indices provides empirical analysis elements of the industry structure and shows the competitiveness dimension. With these indicators it is possible to measure the performance reflected in the participation of the developed economic activities (Possas, 1999; Coelho Junior et al., 2010, 2018).

In the forestry sector, studies that have used concentration indicators were: Hilgemberg and Bacha (2001), Noce et al. (2007, 2008); Costa and Garcias (2009), Coelho Junior et al. (2010, 2013, 2016, 2018), Heimann et al. (2015); Oliveira et al. (2017), Silva et al. (2017), Simioni et al. (2017), Martins et al. (2018) These works diagnosed and better understood the market structures and the concentration degree in their study objects.

Considering the collected evidence, understanding the international MDF market has become necessary. Therefore, this article analyzes the behavior and global MDF production concentration from 1995 to 2016.

\section{MATERIALAND METHODS}

The data from 1995 to 2016 were used for the MDF-producing countries in millions of cubic meters $\left(10^{6} \mathrm{~m}^{3}\right)$. This period was analyzed because the information is available from the statistical division of FAO (FAOSTAT). The time series of the global MDF production was used for analysing the conjuncture in this period, and the evolution of the five largest countries (China, Turkey, Brazil, Poland and the United States) for 2016 and the rest of the world was considered. Also, the top 10 producing countries were selected based on the 2016 top 10 in the ranking and the number of nations participating in world production in the years 1995, 2000, 2005, 2010 and 2016.

Gains and losses in global MDF production were measured by means of the geometric growth rate $(G G R)$ in annual percentage (p.a.\%), according to equation 1 (Cuenca and Dompieri, 2017). 


$$
\text { EQ-1 } G G R=\left[\Delta t \sqrt{\frac{V_{n}}{V_{0}}}-1\right] * 100
$$

In which, $\mathrm{V}_{\mathrm{n}}=\mathrm{MDF}$ production referring to final year in 2016; $\mathrm{V}_{0}^{\mathrm{n}}$ is the MDF production referent to the initial year in $1995 ; \Delta \mathrm{t}$ is the temporal variation of the production (expressed in years).

Industrial concentration indices may be partial or summary. The partial indexes only take into account part of the countries that operate in a certain industry. The summary indices use the data of all the countries that compose the market. The indicators used in this study were: Concentration Ratio [CR( $k)]$; HerfindahlHirschman Index (HHI); Theil Entropy Index $(E)$; Gini Coefficient $(G)$; Hall and Tideman Index (HTI); and the Comprehensive Concentration Index $(C C I)$.

The Concentration Ratio [CR(k)] considered the participation of $k$ (being $k=1,2, \ldots, n$ ) as the largest MDF producing countries, represented by equation 2 .

\section{EQ-2}

$$
C R(k)=\sum_{i=1}^{n} s_{i}
$$

In which, $s_{i}$ is the percentage market share of the country $i$ in the global MDF production.

The $C R(k)$ for the four [CR(4)], the eight [CR(8)] and the $20[C R(20)]$ largest MDF producing countries in the world were calculated. $C R(4)$ and $C R(8)$ were examined according to Table 1 of the Bain (1959) classification.

The Herfindahl-Hirschman Index $(H H I)$ was proposed by Hirschman (1945) and Herfindahl (1950) independently, according to equation 3 .

Table 1 - Classification of the degree of concentration of the largest producing countries.

Tabela 1 - Classificação do grau de concentração dos maiores países produtores.

\begin{tabular}{lcc}
\hline $\begin{array}{l}\text { Concentration } \\
\text { degree }\end{array}$ & $C R(4)$ & $C R(8)$ \\
\hline Very high & $C R(4) \geq 75 \%$ & $C R(8) \geq 90 \%$ \\
High & $65 \% \geq C R(4)>75 \%$ & $85 \% \geq C R(8)>90 \%$ \\
Moderately & $50 \% \geq C R(4)>65 \%$ & $70 \% \geq C R(8)>85 \%$ \\
high & $35 \% \geq C R(4)>50 \%$ & $45 \% \geq C R(8)>70 \%$ \\
Moderately & $C R(4)<35 \%$ & $C R(8)<45 \%$ \\
low & & \\
Low & &
\end{tabular}

$$
{ }^{\mathrm{EQ}-3} H H I=\sum_{i=1}^{n} s_{i}^{2}
$$

In which, $\mathrm{S}_{\mathrm{i}}=$ market share of the country $i$ in the global MDF production; $n=$ number of participating nations in the global MDF production. $H H I$ varies between $1 / n$ and 1 , the lower limit being the one in which all countries have the same size, while there is a monopoly situation (maximum concentration) at the upper limit of the $H H I$.

As proposed by Resende (1994), the adjusted Herfindahl-Hirschman Index (HHI') was used for comparative analysis in the studied period, since there was annual variation in the number of countries in the global MDF production. He used equation 4 for $n>1$.

$$
\text { EQ-4 HHI' }=\frac{1}{n-1}(n H H I-1)
$$

Values of $H H I$ ' $<0.15$ for the $H H I$ 'indicates a nonconcentrated market. A range of $0.15 \leq H H I^{\prime} \leq 0.25$ has moderate concentration. Values of $H \bar{H} I^{\prime}>0.25$ have a high concentration.

The Theil Entropy Index $(E)$ measures the inverse of the concentration, meaning that the lower the index value, the more concentrated the exports are of the particular product being studied. In cases where the index (equation 5) is equal to zero there is a monopoly, which is maximum concentration. The upper limit is equal to $\ln (n)$, and in this situation companies have equal market share, where the concentration is minimal (Resende and Boff, 2002).

$$
\text { EQ-5 } E=-\ln \sum_{i=1}^{n} s_{i}\left(s_{i}\right)
$$

In which, $n=$ number of participating countries in global MDF production; $s_{i}=$ market share of the country $i$ in global MDF production; $l n=$ neperian logarithm.

The Adjusted Theil Entropy Index ( $\left.E^{\prime}\right)$ was proposed by Resende (1994), so that its value could vary between zero (maximum concentration) and one (minimum concentration) for intertemporal analyzes, according to equation 6 .

$$
\text { EQ-6 } E^{\prime}=-\frac{1}{\ln (n)} \sum_{i=1}^{n} s_{i} \ln \left(s_{i}\right)
$$


The Gini Coefficient $(G)$, proposed by Gini (1912), was used to measure the degree of inequality of global MDF production, according to equation 7.

$$
\text { EQ-7 } G=1-\frac{\left[\sum_{i=1}^{n}\left(s_{i j}+s_{i}\right)\right]}{n}
$$

In which, $n$ is the number of MDF producing countries; $s_{i j}$ is the cumulative share of MDF-producing countries in increasing order; $s_{i}$ is the market share of the country $i$ in the global MDF production. The $G$ varies between 0 and 1 and can be classified as follows: $0<\mathrm{G} \leq 0.1$ situation of zero inequality; $0.1<G \leq 0.25$ zero to weak inequality; $0.25<G \leq 0.5$ weak to average inequality; $0.5<G \leq 0.7$ medium to strong inequality; $0.7<G \leq 0.9$ strong to very strong inequality; $0.9<$ $G \leq 0.999$ very strong to absolute inequality; and 1 being absolute inequality.

The Hall and Tideman Index (HTI) inserts the share of each country and each receives a weight equal to its ranking, giving emphasis to the total number of countries producing MDF. The HTI (equation 8) varies from $1 / n$ to 1 , where with 1 the market has high concentration, and $1 / n$ is the perfect equality between producing countries.

$$
\text { EQ-8 HTI }=\left(2 \sum_{i=1}^{n} i S_{i}-1\right)^{-1}
$$

In which $i$ is the position occupied by the country in descending order in the global MDF production; $S_{i}=$ market share of the country $\mathrm{i}$ in the global MDF production.

As proposed by Horvarth (1970), the Comprehensive Concentration Index $(C C I)$ measures both the relative dispersion and the absolute magnitude, solving some deficiencies of the above listed indexes. The $C C I$ (equation 9) represents the sum of the market share of the leading country with the squared sum of the proportional sizes of each country weighted by a multiplier, which reflects the proportional size of the remaining MDF producing countries.

$$
\text { EQ-9 } C C I=s_{1}+\sum_{i=2}^{n} s_{i}^{2}\left[1+\left(1-s_{i}\right)\right]
$$

In which, $\mathrm{S}_{\mathrm{i}}$ is the largest market share among the countries organized in descending order; $\mathrm{S}_{\mathrm{i}}$ is the market share of country $i$ in the global MDF production. The index will be equal to one in case of monopoly, high concentration.

\section{RESULTS}

Figure 1 shows the evolution of the global MDF production and the five largest producing countries based on 2016, in millions of $\mathrm{m}^{3}\left(10^{6} \mathrm{~m}^{3}\right)$, in the period between 1995 and 2016.

Table 2 shows the evolution of the 10 largest MDF producing countries in the world based on 2016, in millions of $\mathrm{m}^{3}\left(10^{6} \mathrm{~m}^{3}\right)$, the number of MDF producing nations and the top 10 in the international ranking for the years 1995 , 2000, 2005, 2010, and 2016.

Figure 2 presents the evolution of concentration indicators of global MDF production from 1995 to 2016 . Figure 2.a shows the Concentration Ratio of the four [CR(4)], eight $[C R(8)]$ and twenty $[C R(20)]$ largest production countries; Figura 2.b the Herfindahl-Hirschman Index (HHI), the lower limit and the adjusted HHI (HHI'); Figure 2.c the Theil Entropy Index (E), the upper limit and the adjusted E (E'); Figure 2.d the Gini Coefficient (G); Figure 2.e the Hall and Tideman Index (HTI) and the lower limit; and Figure 2.f the Comprehensive Concentration Index (CCI).

\section{DISCUSSION}

As shown in Figure 1, global MDF production was 7.88 million $\mathrm{m}^{3}$ (1995) and showed an average annual

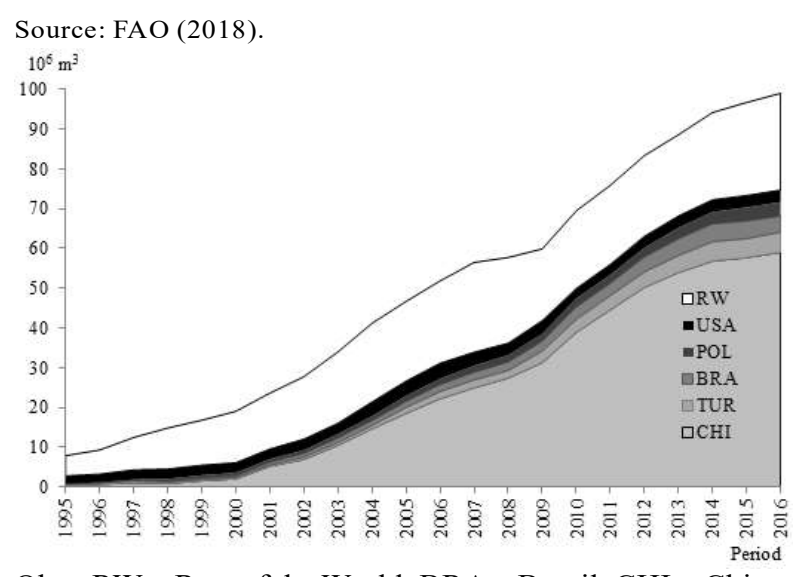

Obs.: $\mathrm{RW}=$ Rest of the World; $\mathrm{BRA}=$ Brazil; $\mathrm{CHI}=$ China; $\mathrm{POL}=$ Poland; TUR $=$ Turkey; USA $=$ United States of America.

Figure 1 - Evolution of world production of MDF and the four largest producing countries in 2016, in millions of $\mathrm{m}^{3}\left(10^{6} \mathrm{~m}^{3}\right)$, from 1995 to 2016 .

Figura 1 - Evolução da produção mundial de MDF e dos quatro países maiores produtores em 2016, em milhões de $\mathrm{m}^{3}\left(10^{6} \mathrm{~m}^{3}\right)$, no período de 1995 a 2016.

Revista Árvore. 2018;42(5):e420506 
Table 2 - Evolution of the 10 largest MDF producing countries based on 2016 , in millions of $\mathrm{m}^{3}\left(10^{6} \mathrm{~m}^{3}\right)$, the number of MDF-producing nations in the world and the top 10 in the international ranking for the years 1995, 2000, 2005, 2010, 2016.

Tabela 2 - Evolução dos 10 maiores países produtores de MDF com base em 2016, em milhões de $\mathrm{m}^{3}\left(10^{6} \mathrm{~m}^{3}\right)$, o número de nações produtoras de MDF no mundo e os top 10 do ranking internacional para os anos de 1995, 2000, 2005, 2010, 2016.

\begin{tabular}{|c|c|c|c|c|c|}
\hline Countries & 1995 & 2000 & 2005 & 2010 & 2016 \\
\hline China & 0.540 & 2.060 & 18.541 & 38.942 & 59.044 \\
\hline Turkey & 0.121 & 0.388 & 1.500 & 3.265 & 5.069 \\
\hline Brazil & - & 0.381 & 1.408 & 3.036 & 4.012 \\
\hline Poland & 0.168 & 0.768 & 1.506 & 2.176 & 3.550 \\
\hline USA & 1.959 & 2.501 & 3.682 & 2.517 & 3.001 \\
\hline Russia & - & 0.215 & 0.446 & 1.078 & 2.595 \\
\hline Thailand & 0.081 & 0.398 & 0.660 & 2.170 & 2.170 \\
\hline South Korea & 0.573 & 0.931 & 1.653 & 1.836 & 1.859 \\
\hline Spain & 0.505 & 1.070 & 1.185 & 0.800 & 1.520 \\
\hline Germany & 0.563 & 2.500 & 3.800 & 1.762 & 1.502 \\
\hline Rest of the world & 3.373 & 7.828 & 12.303 & 11.875 & 14.689 \\
\hline Total & 7.883 & 19.040 & 46.683 & 69.457 & 99.010 \\
\hline $\mathrm{n}^{\circ}$ countries & 28 & 38 & 41 & 48 & 50 \\
\hline $1^{\circ}$ & USA & USA & $\mathrm{CHI}$ & $\mathrm{CHI}$ & $\mathrm{CHI}$ \\
\hline $2^{\circ}$ & ITA & GER & GER & TUR & TUR \\
\hline $3^{\circ}$ & KOR & $\mathrm{CHI}$ & USA & BRA & BRA \\
\hline $4^{\circ}$ & GER & CAN & KOR & USA & POL \\
\hline $5^{\circ}$ & $\mathrm{CHI}$ & SPA & POL & POL & USA \\
\hline $6^{\circ}$ & SPA & KOR & TUR & THA & RUS \\
\hline $7^{\circ}$ & NWZ & FRA & BRA & KOR & THA \\
\hline $8^{\circ}$ & UNK & POL & CAN & GER & KOR \\
\hline $9^{\circ}$ & FRA & ITA & MAL & MAL & SPA \\
\hline $10^{\circ}$ & POR & UNK & SPA & RUS & GER \\
\hline
\end{tabular}

growth of $12.81 \%$ p.a., reaching 99 million $\mathrm{m}^{3}$ in 2016. Based on the 2016 ranking, the five largest producing countries were China, Turkey, Brazil, Poland and the United States. Until 2000, the United States was the world leader in the MDF supply. From 2001 to 2016 , China took the lead and grew $17.54 \%$ p.a., from 5.22 million $\mathrm{m}^{3}$ (2001) to 59 million $\mathrm{m}^{3}$ in 2016. During this period, annual rates for Turkey were $19.38 \%$ p.a., Brazil 13.39\% p.a., Poland 10\% p.a., the United States with $1.19 \%$ p.a., and the rest of the world at $3.73 \%$ p.a.

The growth in the global MDF production was also a reflection of greater use of the product in several sectors such as furniture, which replaced solid wood by MDF in the manufacture of several items due to the scarcity of raw material, which in turn affected the selling price of timber, thus favoring substitution (Selvatti, 2015). According to Vidal and Hora (2014), the global consumption of wood panels is related to income, consumption distribution of panels between countries, habits, cultural patterns and local supply of products. In addition, according to the authors, this consumption grew more than the world GDP.

In 1997, MDF production in Brazil had its first registrations by the FAO statistical division and ranked $25^{\text {th }}$ out of the 28 producing countries. With growing trends in 2002, it ranked $10^{\text {th }}$ in the world ranking. Producing a quality product and with high demand in the domestic furniture sector, the national supply reached the top 5 in 2006, and as of 2010 it occupied and remained at $3^{\text {rd }}$ best in the world (FAO, 2017).

Brazilian MDF production was slow to present significant results when compared to the largest world producers. However, this prominent position was quickly 

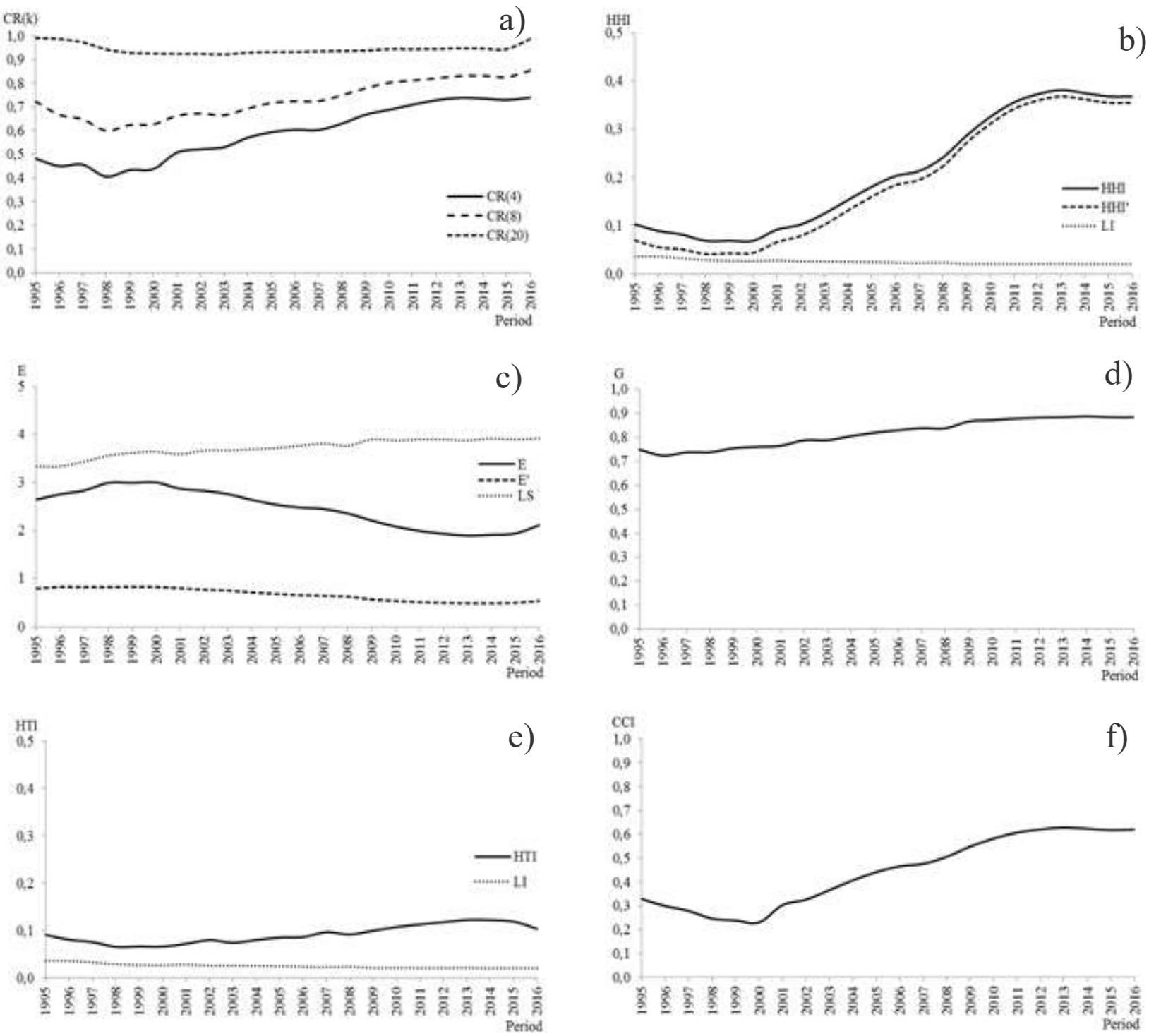

Figure 2 - Evolution of indicators of world concentration of production of MDF, from 1995 to 2016. Concentration ratio of the four [CR(4)], eight [CR(8)] and twenty [CR(20)] major producers (2a); Herfindahl-Hirschman Index (HHI), Lower Limit ( $L I)$ and Adjusted Herfindahl-Hirschman Index (HHI') (2b); Theil Entropy Index (E), Upper Limit $(L S)$ and Adjusted Theil Entropy $\left(E^{\prime}\right)(2 \mathrm{c})$; Gini index $(G)(2 \mathrm{~d})$; Hall and Tideman Index $(H T I)$ and Lower Limit $(L I)(2 \mathrm{e}) ;$ Comprehensive Concentration Index $(C C I)(2 \mathrm{f})$

Figura 2 - Evolução dos indicadores de concentração da produção mundial de MDF, no período de 1995 a 2016. Razão de Concentração dos quatro [CR(4)], oito [CR(8)] e vinte [CR(20)] maiores produtores (2a); Índice de HerfindahlHirschman (HHI), Limite Inferior (LI) e Índice de Herfindahl-Hirschman ajustado (HHI') (2b); Índice de Entropia de Theil (E), Limite Superior (LS) e Entropia de Theil ajustado (E') (2c); Índice de Gini (G) (2d); Índice de Hall e Tideman (HTI) e Limite Inferior (LI) (2e); e Índice de Concentração Compeensiva (CCI) (2f).

acquired so that Brazil remained among the main producers. This type of panel manufacturing technology was due to economies of scale in domestic production (Selvatti, 2015).
Table 2 shows that the total number of MDF producing nations increased from 28 countries (1995) to 50 (2016). The 10 largest MDF-producing countries in 2016 accounted for $85 \%$ of world production, with

Revista Árvore. 2018;42(5):e420506 
only China accounting for about $60 \%$. According to the evolution of the top $10 \mathrm{MDF}$ producing countries from 1995 to 2016, hegemony of the United States is observed between 1995 to 2000 and reached the end of the series in $5^{\text {th }}$ place. China started in $5^{\text {th }}$ place and took the lead in the world's MDF supply from 2001. Turkey came out of $15^{\text {th }}$, where it gradually increased in the world ranking, reaching the top 2 in 2010, and remained until 2016. In 1997, Brazil occupied the $25^{\text {th }}$ position, and from 2002 it was among the 10 largest global MDF producers, and was gradually gaining positions starting in 2016 as the $3^{\text {rd }}$ largest producer in the international ranking. Germany started in $4^{\text {th }}$ place, finishing $2^{\text {nd }}$ in the period from 1997 to 1998 , then losing positions and finally taking $10^{\text {th }}$ place in the world. Among the top 10 of 2016 , Poland $\left(14^{\text {th }}>\right.$ $\left.4^{\text {th }}\right)$, Russia from $1999\left(21^{\text {st }}>6^{\text {th }}\right)$, Korea $\left(3^{\text {rd }}>8^{\text {th }}\right)$ and Thailand $\left(18^{\text {th }}>7^{\text {th }}\right)$.

Figure 2.a observed an increasing concentration trend for both the four [CR(4)] and the eight [CR(8)] largest MDF producers between 1995 and 2016. By classifying according to Bain (1959), the $C R(4)$ had moderately low concentration in the first six years $(1995-$ 2001) and had the lowest concentration 1998 (40.54\%). From 2001, the $C R(4)$ moved to a moderately high and increasing concentration. Still with an increasing tendency in 2009 , the concentration went to high and the Concentration Ratio reached its highest value in 2013 (73.84\%), with 48 producing countries. However, in the following years there was a small reduction in share by the four largest producers, but not enough to change the concentration classification of MDF production. The data show that there was a share increase of the four largest producers during the study years.

Through CR(8) it was observed that the global MDF production presented moderately high concentration in 1995. Then from 1996 to 1998 , the $C R(8)$ share decreased due to the reduced participation of the eight largest producers, until the year the concentration reached its lowest value of $59.94 \%$ (1998), classifying the concentration as moderately low. This behavior occurred when there was an increase in the number of countries from 28 to 35 , from 1996 to 1998. Thus, the concentration reduced with the entry of new countries into the MDF production market. $C R(8)$ then increased again in the following years, but without changing the concentration classification. With small fluctuations in the following years, the share of the eight largest producers rose again in 2005, and from there it was again classified as moderately high until the end of the study period.
The $20[C R(20)]$ largest MDF producing countries had an average of $94.14 \%$ share in the global production in the studied period, with the lowest share being in 2003 (92.14\%) and the highest share in 1995 (99.12\%). Therefore, despite the growth from 28 to 50 countries, there was a dominance of the $C R(20)$, and it was also verified that concentration increased since 2003 due to greater share of $C R(4)$ and $C R(8)$ in the global supply of MDF.

As can be seen in Figure 2.b, the evolution of the Herfindahl-Hirschman Index $(H H I)$ showed a reduction in the concentration at the beginning of the period, and from 2001 there was an increasing tendency in the global MDF production concentration. This deconcentration can be observed by the approximation of the HHI and the lower limit, and thus there was no difference between the production of the various countries. However, this distance between the lower limit and the index becomes larger from 2001, and so the concentration increases and reaches its highest value in 2013 (0.3811).

Similar behavior was also observed in the adjusted $\mathrm{HHI}^{\prime}$ index (Figure 2.b), where there was an increase in concentration considering the variation of existing countries. The reduction occurred between 1995 and 1998, and the concentration after this year was increasing, also reaching the highest concentration in 2013. The index classification also shows this increase in concentration, since the values were lower than 0.15 between 1995 and 2004, thus characterizing a non-concentrated market. It then became moderate between 2005 and 2008, and in the last years of the period it is considered high, especially in 2013, with the highest verified value (0.3811).

Figure 2.c shows the evolution of the Theil Entropy Index, where it is possible to observe an increasing tendency in the global MDF production concentration with a falling index trend, since this represents the inverse of the concentration. Thus, the lowest concentration was verified in 2000 (3.0001). There was then a reduction in concentration during 1995 to 2000 , even as the number of producing countries increased. The concentration increased after 2000, until reaching the highest value in 2013 (1.8946).

The increase in concentration can still be verified by the distance between the index value and its upper limit (situation where all countries would be equal). This distance was lower in the year 2000, and showed an increasing behavior after this year. The behavior of the adjusted index also represented an increase in the MDF production concentration in the analyzed period.

Revista Árvore. 2018;42(5):e420506 
According to the Gini Coefficient $(G)$ represented in Figure 2.d, the inequality in global MDF production could be classified as strong to very strong during the whole period. The lowest $G$ found was $1996(0.7239)$, and the highest was found in 2014 (0.8887). The increase in the number of countries producing MDF was not enough to reduce inequality in the period; on the contrary, inequality increased. Although small oscillations occurred in $G$ in some years, inequality remained classified as strong to very strong. The reason for this increase was the significant growth in production in the countries, especially China, even though there is an insertion of nations in the MDF supply, there was no scale to reduce the disparity of this market.

It can be observed in Figure 2 that HTI showed increased concentration tendencies for the global MDF supply from 1995 to 2016. HTI was more sensitive when compared to other analyzed indicators, reducing in the first years, but an increase in the global MDF production concentration can be seen after 1998. This increase can also be noticed by the distance between HTI and its lower limit.

The Comprehensive Concentration Index found similar behavior to the Herfindahl-Hirschman Index; a concentration reduction trend in the first years up to the year 2000, and then there was concentration growth, even with the same occurring with the number of countries producing MDF (Figure 2.f). This index also highlighted that there has been an increase in the share of the main producer in total MDF produced (China) over the years.

Thus, an increase in global MDF production was verified when China started to have a prominent role in the world production, and new countries also became part of this market with the increase in the demand for the product, but their production levels were not enough to change the impact of Chinese production in the world scenario.

\section{CONCLUSIONS}

In view of the above, it is concluded that:

Global MDF production grew $12.81 \%$ p.a. from 1995 to 2016 , reaching 99 million $\mathrm{m}^{3}$ at the end of the time series. China took over hegemony in 2001 and arrived in 2016 with about $60 \%$ of the world's MDF supply.

Revista Árvore. 2018;42(5):e420506

Revista Árvore. 2018;42(5):e420506
$C R(k)$ of the global MDF production resulted in a high concentration, mainly in the $C R(4)$ as of 2009. The $C R(8)$ remained with a moderately high average concentration. During this period more than $90 \%$ of the supply was retained in the $C R(20)$.

The HHI, E and HTI indices corroborate that there is high concentration in the global MDF production, as well as the $C C I$ in the studied period. The inequality indicated by $\mathrm{G}$ also presented increasing behavior and was classified as strong and very strong. Even the increase in the number of MDF-producing countries during the period was not enough to reduce concentration and inequality, as the Chinese MDF share was still very high in world production.

The concentration indicators were efficient in evaluating the concentration degree of the global MDF supply.

\section{REFERENCES}

Bain J. Industrial organization. New York: J. Wiley; 1959.

Biazus A, Hora AB, Leite BGP. Painéis de Madeira MDP e MDF - Mercado e Competitividade. Revista da Madeira. 2013(136). [acesso em 24 jan. 2018]. Disponível em: http:// www.remade.com.br/br/ revistadamadeira_materia.php?num $=1683 \&$ subject $=$ Pain $\%$ E9is\&title=Pain $\%$ E9is $\% 20 \mathrm{de} \% 20$ Madeira $\%$ $20 \mathrm{MDP} \% 20 \mathrm{e} \% 20 \mathrm{MDF} \% 20 \% 96 \% 20$ Mercado $\% 20 \mathrm{e} \%$ 20Competitividade

Campos CI, Lahr FAR. Painéis produzidos com pinus. Revista da Madeira. 2004(83) ago. 2004. [acessado em: 10 nov. 2014]. Disponível em: http://www.remade.com.br/br/revistadamadeira materia.php? num $=614 \&$ subject $=$ Pain $\%$ E9is\&title $=$ Pain\%E9 is\%20produzidos\%20com\%20pinus.

Costa F, Garcias PM. Concentração de mercado e desempenho das indústrias brasileiras de papel e celulose-recorrendo à modelagem de Fleuriet para analisar o paradigma ECD. Revista de Contabilidade e Organizações. 2009;3(6):14363.

Coelho Junior LM, Rezende JLP, Avila ES, Oliveira AD, Borges LAC. Analysis of the brazilian cellulose industry concentration (1998-2007). Cerne. 2010;16:209-16. 
Coelho Junior LM. Concentração regional do valor bruto de produção do pinhão no Paraná. Ciência Florestal. 2016;26:853-61.

Coelho Junior LM, Rezende JLP, Oliveira AD. Concentração das exportações mundiais de produtos florestais. Ciência Florestal. 2013;23:693-703.

Coelho Junior LM, Selvatti TS, Alencar FV, Santos Junior EP, Borges LAC, Rezende JLP. Global concentration of pulp exports.. Floresta. 2018;48(4):443-52.

Cuenca MAG,Dompieri MHG. Dinâmica espacial da canavicultura e análise dos efeitos sobre o valor bruto da produção, na região dos tabuleiros costeiros da Paraíba, Pernambuco e Alagoas. Revista Econômica do Nordeste. 2017;47(4):91-106.

Food and Agriculture Organization of the United Nations - FAO. FAO statistics division. Rome, 2017. [accessed: 19 sept. 2017] Available in: http:// faostat3.fao.org/faostat-gateway/go/to/docuenca wnload/F/*/E

Food and Agriculture Organization of the United Nations - FAO. Global forest products facts and figures. [accessed: 10 jun. 2014]. Available in: http://www.fao.org/forestry/35445-

06bb3283bef3163fab71492f6e3cfd8c5.pdf.

Gini C. Variabilità e mutabilità. In: Pizetti E, Salvemini T, editors. Reprinted in memorie di metodológica statistica. Rome: E. V. Veschi; 1912.

Heimann JP, Gonçalves K, Dresch AR, Silva JCGL. Concentração de mercado de molduras (frame) importadas pelos Estados Unidos, período de 2005 a 2009. Cerne. 2015;21(1):59-65.

Herfindahl OC. Concentration in the steel industry (thesis). 1950. New York: Columbia University; 1950

Hilgemberg EM, Bacha CJC. A evolução da indústria brasileira de celulose e sua atuação no mercado mundial. Revista Análise Econômica. 2001;19(36):145-64.

Hirschman AO. National power and the structure of foreign trade. Berkley: University of California; 1945.
Horvarth J. Suggestion for a comprehensive measure of concentration. Southern Economic Journal. 1970;36:446-52.

Instituto Brasileiro de Árvore - IBÁ. Relatório anual 2014. [accessed in: 04 dec. 2014]. Available in:http://www.bracelpa.org.br/shared/ iba_2014_pt.pdf

Instituto Brasileiro de Árvore - IBÁ. Relatório anual 2017. [accessed in: 24 jan. 2018]. Available in: http://iba.org/images/shared/Biblioteca/ IBA RelatorioAnual2017.pdf.

Lopez R, Lopez E, Lirón-España C. Who benefits from industrial concentration? evidence from U.S. manufacturing. Journal of Industry, Competition and Trade. 2014;14(3):303-17.

Martins KLC, Melquiades TF, Rezende JLP, Coelho Junior LM. Plant extractivism production disparity between Northeast Brazil and Brazil. FLORAM. 2018;25:e20160456.

Noce R, Silva ML, Souza AL, Silva OM, Mendes LM, Carvalho RMMA, Valverde SR.

Competitividade do Brasil no mercado internacional de aglomerado. Revista Árvore. 2008;32(2):245-50.

Noce R, Carvalho RMMA, Canto JL, Silva ML, Mendes LM. Medida da desigualdade do mercado internacional de compensado. Cerne. 2007;13(1):107-10.

Oliveira GS, Silva MTS, Novack Junior NS, Lambert L, Atanazio KA, Soares PRC. Concentração das exportações brasileiras de portas de madeira. Scientia Agraria Paranaensis. 2017;16(4):490-4.

Possas MS. Concorrência e competitividade: notas sobre estratégia e dinâmica seletiva na economia capitalista. São Paulo: Hucitec; 1999.

Selvatti TS. Concentração da produção e da exportação mundial de celulose e de Medium Density Fiberboard (MDF) [dissertação]. Lavras: Universidade Federal de Lavras; 2015.

Silva MTSD, Oliveira GS, Dreyer TC, Severo DDS, Soares PRC. Desigualdade e concentração nas exportações brasileiras de painel compensado. Revista Espacios. 2017;38(31):7.

Revista Árvore. 2018;42(5):e420506 
Simioni FJ, Moreira JMMAP, Fachinello AL, Buschinelli CCA, Matsuura MISF. Evolução e concentração da produção de lenha e carvão vegetal da silvicultura no Brasil. Ciência Florestal. 2017;27:731.

Resende M. Medidas de concentração industrial: uma resenha. Revista Análise Econômica. 1994;12(21):24-33.

Resende M, Boff H. Concentração industrial. In: Kupfer D, Hasenclever L, organizadores.
Economia industrial: fundamentos teóricos e práticas no Brasil. Rio de Janeiro: Campus; 2002. p.73-90.

Vidal ACF, Hora AB. Panorama de mercado: painéis de madeira. BNDES Setorial. 2014;40:323-84.

Zheng D, Kuroda T. The impact of economic policy on industrial specialization and regional concentration of China's high-tech industries. The Annals of Regional Science. 2013;5(3):771-90.

\section{ERRATA}

No artigo "GLOBAL PRODUCTION CONCENTRATION OF MEDIUM DENSITY FIBERBOARD (MDF) (1995 - 2016)”, publicado no número 5, volume 42, da Revista Árvore, onde se lê:

Thaisa de Sousa Selvatti ${ }^{2}$, Luis Antônio Coimbra Borges ${ }^{3}$, Helena Cristina Carvalho Soares Antônio ${ }^{4}$,Álvaro Nogueira de Souza ${ }^{5}$ and Luiz Moreira Coelho Junior ${ }^{6 *}$

L eia-s e:

Thaisa de Sousa Selvatti ${ }^{2}$, Luis Antônio Coimbra Borges ${ }^{3}$, Helena Cristina Carvalho Soares ${ }^{4}$,Álvaro Nogueira de Souza ${ }^{5}$ and Luiz Moreira Coelho Junior ${ }^{6 *}$ 